ment. It is thus impossible to discuss the proper value of $\mathrm{P}_{0}$, as Prof. Harkness wishes to clo, without raising the question of fallible observations. If it is raised, the method of treatment by least squares follows.

Prof. Harkness tried to show that, although the second term which I introduced brought the approximate value of $P_{0}$ nearer to that given by the ordinary formula, it removed it further from another value which he regarded as the standard. I venture to think that I have justified my position by showing that the introduction of $\mathrm{P}_{0}$ is useless unless the equations are regarded as fallible; that the ordinary value is that given by least squares, and that the standards proposed by Prof. Harkness are founded on assumptions which have no theoretical basis.

In conclusion I may perhaps be allowed to make two remarks, ne of which would, I think, from the point of view assumed by Prof. Harkness have strengthened his case. In the first place he is wrong in saying that the ordinary value of $\mathrm{P}_{0}$ lies between $\mathrm{P}$ and $\mathrm{P}_{1}$. It is smaller than both of them if $\mathrm{A}$ is $>\mathrm{A}_{1}$.

In the next place I may point out that by treating a number of fallible expressions of the type of equations ( $I$ ) and $(2)$ by the method of least squares, a general value of $\mathrm{L}$ could be found without the introduction of the small theoretical errors which have caused this correspondence. There is however little doubt that by the introduction of $\mathrm{P}_{0}$ we obtain a more convenient and practically no less accurate method of dealing with the observations. ARTHUR W. RÜCKER.

Science Schools, South Kensington, January to.

\section{The Mist-Bow.}

IN a letter to the Times of Jantary 12 , Prof. Tyndall calls attention to a white mist bow, which he has seen on one or two occasions, and mentions its rarity of occurrence. It may therefore be of interest to record that I witnessed a similar phenomenon on January 9 last. My point of view was an elevated band-stand at the head of Veymouth Pier; the time II a.m. The air, as on the occasions mentioned by Prof. Tyndall, "swarmed with minute aqueous particles," i.e. was toggy, and on looking away from the sun, which was shining weakly, I saw a well-defined white bow cast upon the mist. The bow appeared to be about 60 feet distant. My point of view being high, a full semicircle was visible. It was, as may be imagined, a beautiful and graceful object.

St. Leonard;, Exeter, January 13.

IN reference to Dr. Tyndall's letter in the Times of Thursday last upon the ullao as observed by hin, I bey to call your attention to my paper rend before the Stockport Society of Naturalists upon the same subject (see pp. II and 35). Not having seen the phenomenon described before, I ventured to clll it the dew-bow.

Morfield, Stockport, January I4.

TrE charicter and persistence of the recent fog have been so exceptional that perhaps you may deem the following observa. tions on it worthy a record in NATURE.

I was staying in Mid-Devon at a place in the valley of the River Taw, some ro miles north of Dartmoor. On Monday, the 9 th instant, we were enveloped in a dense, damp, white fog, a rare occurrence in that part of the country. Surmising that the fog had no great vertical thickness, I sallied forth in the afternoon to mount a hill immediately to the eastward. At a slight elevation the sun was already making his appearance, and as I continued my ascent, and the for became more and more thin, I saw before me on the then pale blue sky a beautiful white bow, similar to the rainbow, only broader and without colour. When the top of the hill was reached, the fog and bow had disappeared, the sky was deep blue, and the sun shining with quite spring like warmth.

The scene I now had around me was most enchanting. The fog could be traced lying in the river valleys like arms of the sea, with the bordering hills simalating cliffs, and here and there an island appearing in the midst, whilst the distant Dart. moor hills stood out calm in unbroken sunshine. No movement of the air could be detected, but, below, the surface of the fog seemed as if being rolled along by a wind from the east towards the river valley. The white fog-bow is selciom seen, and I imagine owes its absence of colour to the minuteness and close proximity of the water globules, allowing the divided rays to coalesce and so again form white light.

\section{Atmospheric Effects at Sunset.}

ON Sunday, January 8 , upon leaving the house at half-past four in the afternoon, I observed that the clouds were suffused with a kind of pink or lurid coppery tinge, a sort of angry sunset tint spread over the whole sky. The clouds were of the stratus type which is common in a winter anticyclone, but were moving or rather driving with a swiftness quite unusual under such conditions. The barometer was very high and rising rapidly; but during the afternoon there were several violent and noisy gusts of wind almost amounting to squalls, though during the greater part of the day the atmosphere was still almost to stagnation. The air was mild and intensely humid, and everything was dripping with moisture. In fact the weather was in many particulars the opposite of what we expect during the prevalence of an anticyclone. The diffused sunset effects were quite unlike anything I ever remember to have witnessed before. The gas-lamps had just been lit, and the flames not only appeared of a greenish tint, but seemed to be inclosed in green glass. Several persons stopped me in the street and inquired what it all meant, and one acquaintance said, "What is going to happen?" In the green tint of the gas there is, of course, some suggestion of a colour complementary to the strange red glow which seemed to pervade the atmosphere. But in the abience of all, even the most rudimentary, knowledge of the subject, I should be glad if you or some of your readers can explain the cause to me and to others who witnessed the unaccustomed phenomenon.

Prestwich, near Manchester, January 9. Charles Croft.

\section{Newton's "Principia."}

IT may perhaps interest your reaters to know that the 200th anniversary of the publication of Newton's "Principia" was solemnly celebrated on December 20 (old style) by a united meeting of two learned Societies of Moscow - the Imperial Society of Friends of Natural Knowledge, and the Mathematical Society. Prof. Mendeléeff, of St. Petersburg, was Honorary President. Prof. Stoletow (President of the Physical Section in the firstnamed Society) presented a sketch of Newton's life, and spoke on his optical discoveries; Prof. Zinger (President of the Mathematical Society) treated Newton's mathemutical work Prof. Joukowski pointerl out his merits as founder of rational dinnamics ; and Prof. Ceraski exhibited the creation of celestial mechanics by Newton. The large hall of the Polytechnic Museum, where the meeting took place, was attended by the clite of the city. The lectures were illustrated by some optical experiments with electric light and some lantern-slides relative to Newton's biography.

University of Moscow, December 2I, I887

$$
\text { (January 2, 1888). }
$$

A. STOLETOW.

\section{Meteors.}

IN the moonlight on the evening of January 2 , at $10 \mathrm{~h} .58 \mathrm{~m}$., a fine meteor, equal in brightness to Jupiter, was observed by Mr. D. Booth at Leeds, and by myself at Bristol. As seen from Leeds, the meteor passed from Musca to the head of Cetus, and terminated its course about $3^{\circ}$ east of $\alpha$ Ceti. It moved rather quickly, leaving a long thin train. The fore-part of the nucleus was tinted with red, but the train was yellow. At the finish the motion became slower. At Bristol the meteor was first seen when about $6^{\circ} \mathrm{S}$.E. of $\zeta$ Draconis, and it travelled some $8^{\circ}$ in the direction of $\beta$ Cephei. Colour yellow, motion very slow. The course was evidently much foreshortened close to its radiant.

Comparing the two paths, it will be found that they intersect each other at $250^{\circ}+57^{\circ}$, so that the meteor was not a member of the January Quadrantids, which attain a maximum on January 2, but belonged to a neighbouring shower of Draconids, which, between January 14 and 19 , I have previously observed at $253^{\circ}+56^{\circ}$. The meteor appears to have been observed earlier in its flight at Bristol than at Leeds, for at the latter place the observer was watching the southern sky, and only caught the later part of the course. From a mean of the two observations the height at commencement was 98 miles above a point west of Appleby, Westmoreland, and the end occurred at 60 miles above Chester. The earth-point was near Tiverton, in Devonshire. The real length of path was Io9 miles, and it was inclined at an angle of $20_{2}^{\circ}$ to the horizon. The meteor was travelling in a direction from north to south, the bearing of the radiant being $\mathrm{N} .8 \frac{1}{2}^{\circ} \mathrm{E}$. 